\title{
Survey of Supply and Demand for Poplar Wood in Ontario
}

\author{
by
}

John J. Balatinecz ${ }^{1}$ and Peter M. Morley ${ }^{2}$

At the seventh annual meeting of the Poplar Council of Canada at Timmins in October 1985, some concern was raised about future supply and demand prospects for poplar wood in Ontario. Ed Marcus, head of Timber Sales for the Ontario Ministry of Natural Resources, chaired a panel of industry speakers dealing with this subject. During the presentations and discussions that followed, it was pointed out that the annual harvest of aspen poplar has grown from about 1.0 million $\mathrm{m}^{3}$ in 1974 to 2.6 million $\mathrm{m}^{3}$ in $1984-85$ in Ontario. Although most of this increase can be attributed to the use of poplar for waferboard, increases had also occurred as furnish for hardwood kraft and poplar lumber. Mr. Marcus noted that for the first time ever, he found himself in the position of having to referee conflicting claims over poplar allotments.

As a followup on this panel discussion, the Poplar Council decided that it would be worthwhile to know how members of Ontario's forest industry viewed the poplar wood supply/ demand situation both now and for the future. A short questionnaire was therefore compiled and mailed out in mid May 1986 to 18 companies in the industry. Questions asked included the volume of poplar harvested or purchased by the company during the past year, and what product or products were manufactured from such poplar furnish. The respondents were also asked whether they were concerned about future supply, and finally whether they had embarked upon, or were interested in, establishing test plantations of hybrid poplar close to their mills.

Results of the survey have now been compiled and analysed. The high rate of response, $89 \%$, was impressive, and we are grateful to the companies for contributing their time and sharing their views with us. Companies that we failed to contact will be included in the next national survey which we propose to initiate on behalf of the Poplar Council of Canada in the spring of 1987.

A summary of the survey results is presented below.

Number of companies queried Number of companies responding Number of companies presently using poplar to some degree

\footnotetext{
1 Professor of Wood Science and Forest Products, Faculty of Forestry, University of Toronto.
}

2Peter M. Morley Associates, 778 Avenue Rd., Toronto.
Information supplied by these 14 poplar using companies to specific questions was as follows:

\section{(1) The poplar harvest:}

Total volume of poplar harvested or purchased during the last operating (or calendar year) was $2834000 \mathrm{~m}^{3}$. With one exception this was all aspen, either trembling or largetooth. One company uses a small percentage of black or balsam poplar in its pulpwood furnish. This relatively high volume is both encouraging and startling. It is encouraging because it indicates a substantial growth in poplar harvest in Ontario during the last few years. It is startling because it represents a much larger poplar harvest from these companies than Marcus reported for all of Ontario in 1985.

\section{(2) Products or Processes}

(a) Pulp and paper (kraft, groundwood, pulps for fine paper, linerboard, and corrugating medium). Poplar used for groundwood pulps was about $12-15 \%$ of the total groundwood mill furnish.

(b) Lumber

(c) Veneer and plywood

(d) Waferboard and particle board.

\section{(3) Concern about future supply}

Companies using aspen for pulp or reconstituted board had no immediate concern about future supplies. Several felt that the resource was still greatly underutilized. By contrast, companies harvesting or purchasing poplar for lumber or veneer were greatly concerned about the supply of quality logs for the future. One company with two pulp mills in eastern Ontario had found itself faced with local shortages, and had taken steps to remedy this situation.

\section{(4) Interest in trial hybrid poplar plantations.}

Most companies using poplar for pulp were not interested in hybrid poplars because of the supply situation. But, one pulp company in eastern Ontario has established plantations on a fairly large scale. Of the veneer companies, some either had a program underway or were interested in getting one established.

In conclusion, results of the survey are both encouraging and useful. Survey results have been mailed to all participating companies and will provide a guide for the national survey to follow. 